\title{
Obituary
}

\section{Kees van Rees (1942-2018)}

It is with great sadness that we report the passing of Kees van Rees. Kees died on September 13 and was buried on Saturday September 22 in Amsterdam. As most readers of Poetics will know, Kees was the Editor-in-Chief of Poetics between 1991 and 2009. He turned the journal from one focused on empirical literary studies into the journal it is today: the premier journal for empirical studies on culture, arts and media; dominant in the field of cultural sociology, but also respected in the adjacent fields of psychology of aesthetics, cultural economics, and communication science.

Kees studied French language and literature, philosophy and linguistics at the Free University of Amsterdam. After his graduation (cum laude) in 1967, he received a grant from the French government for a study abroad period at the Ecole Pratique des Hautes Etudes in Paris. In 1970 he started teaching at the Free University in the Faculty of Arts, where he became an Associate Professor in 1976. Although he wrote large parts of his doctoral dissertation there, he defended his PhD thesis in 1986 at the Groningen University. By that time, he had already an appointment at Tilburg University, where he joined the Department of Language and Literature in 1981. From 1986 to 2007, Kees was Associate Professor of Sociology of Culture at that university. He was also twice appointed a visiting research fellow in the Department of Sociology at Princeton University (1999-2000; 2005-2007). After his retirement, he joined the Erasmus University Rotterdam (Erasmus Research Centre of Media, Communication and Culture) as a research fellow for more than a decade. He was also active as a guest researcher at the University of Amsterdam (Department of Sociology).

The development of Poetics has followed in many ways the development of Kees' own research career. In the 1970s, Kees began collaborating with Hugo Verdaasdonk - also a graduate in French literature - and together they started a research program which explicitly challenged the then dominant hermeneutic approaches in the field of literary studies. Their often polemic texts met quite some resistance in this field, and this was in fact the main reason why Kees' dissertation was only accepted in 1986. In 1977, Kees published (together with Verdaasdonk) for the first time in Poetics - which at that time still had the subtitle "International Review for the Theory of Literature". In 1980, Kees became Associate Editor of Poetics, joining the new Editor-in-Chief, Siegfried J. Schmidt, who also sought to advance the empirical study of literature. In the course of that decade Kees started to build the foundations of what become the Poetics we know from the 1990s and beyond.

An important factor in his development was the stimulating environment that the new Department of Language and Literature at Tilburg University offered. In 1981, Verdaasdonk had been asked to become professor in Tilburg, but he would only accept his chair if he was allowed to take Kees with him, since he considered him indispensable to build the new department and new study program. Together they built the research group and study program into the Sociology of Literature, which was later renamed into Marketing and Sociology of Books.

One of their sources of inspiration was the work of sociologist Pierre Bourdieu, who had published La Distinction in 1979 - a book which criticized the charismatic ideology behind common notions of artistic value in a similar vein as Kees and Hugo had done in 1970s from a literary studies perspective. The institutional analysis of cultural production (and consumption) which was placed instead of this, offered a taste of empirical social-scientific research that excited the theoretically trained tandem Verdaasdonk/Van Rees tremendously (Verdaasdonk \& Van Rees, 1977). While the book (and Bourdieu) would conquer the academic world in the decades to come (particularly after the English translation in 1984), Kees was quick to read the French version and built personal contacts with Bourdieu in those years. Bourdieu visited Tilburg University several times in the 1980s. Some of the first Englishlanguage publications of Bourdieu were published in Poetics as a result of these contacts (Bourdieu, 1983, 1985) in special issues edited by Kees. In the same period, Kees first made contact with the (rising) stars of American cultural sociology: Richard A. Peterson, Paul DiMaggio (both first published in Poetics in the 1985 special issue Empirical sociology of cultural productions, Peterson, 1985; Dimaggio \& Stenberg, 1985) and Wendy Griswold (first Poetics publication in the 1987 special issue on reading). These contacts would fuel the transformation of Poetics in the 1990s. In 1989 the subtitle of the journal changed to "Journal for Empirical Research on Literature, the Media and the Arts" (in 1999, "Literature" was replaced by "Culture"). 
Meanwhile, the Department of Language and Literature at Tilburg University was making a name in the Netherlands for being the only empirically oriented Humanities department in the Netherlands in the 1980s. By offering courses in sociology, marketing, and policy, students were prepared for positions in institutions in the literary and cultural field (publishers, libraries, councils for cultural policy, educational consultants, museums, etc.). Among the first graduates were Susanne Janssen and Wouter de Nooy (who later would become, respectively, Editor-in-Chief and Editorial Board Member of Poetics). Kees was co-promotor for their PhD theses in the early 1990s. Later graduates include one of the current Editors-in-Chief, Marc Verboord, for whom Kees served as PhD supervisor in the early 2000 s.

In 1991, Kees became Editor-in-Chief of Poetics, and changed the direction of the journal more profoundly. Whereas Schmidt had emphasized the empirical study of literature (with as culmination the start of the Internationale Gesellschaft für Empirische Literaturwissenschaft (IGEL) in 1987), Kees unmistakably made the journal more sociological. He asked Paul DiMaggio to become Associate Editor in 1992 (originally together with psychologist Mihaly Csikszentmihalyi) and explained this as follows: "Their background and excellent empirical social-science research underscore a shift in the journal's focus that has been under way for several years. The new subtitle, added in 1989, demonstrates the journal's interest in publishing research on media and the arts as well as literature; besides, the new subtitle emphasizes the journal's commitment to empirical research (defined broadly to include qualitative as well as quantitative empirical studies)." (Van Rees, 1992: xi). This statement still stands as Poetics' manifesto.

In the two decades that followed, Kees managed to make Poetics a frontrunner: always in touch with the latest developments in the field, initiating exciting special issues, and giving the floor to new and inspirational ideas. Under his editorship Poetics published one of Peterson's first articles on cultural omnivores (Peterson, 1992), one of John Mohr's first articles on meaning and measurement (1994 in a special issue guest-edited by DiMaggio; Mohr, 1994), early work by Michele Lamont on cultural boundaries (Lamont et al., 1996), one of the first articles by Tia DeNora on music as a technology of the self (DeNora, 1999), one of the first articles by Omar Lizardo on cultural capital and institutional theory (Lizardo, 2005), but also influential work on literary reception by scholars such as David Miall, Don Kuiken, David Hanauer, Gerald Cupchick and Karl Erik Rosengren. There were special issues on, to mention a few, emotions and culture (Frijda \& Schram, 1995), museum research (DiMaggio, 1996), status and taste display (Peterson, 1997), conditions of cultural production and reception (Griswold, Janssen \& Van Rees, 1999), relational analysis and institutional analysis (Mohr, 2000), culture and cognition (Cerulo, 2000), the sociology of music (Dowd, 2002), gender, networks and cultural capital (DiMaggio, 2004), music in society (Peterson \& Dowd, 2004), culture and classification in markets (Breiger, 2005), comparative research on culture (Janssen \& Peterson, 2006), the digital divide (Roe, 2006), sociology of fashion (Crane \& Bovone, 2006), social status and cultural consumption (Chan \& Goldthorpe, 2007), boundary work (Pachucki, Pendergrass \& Lamont, 2007), cultural omnivorousness (Ollivier, van Eijck \& Warde, 2008), classifying culture (Baumann, Dowd \& Janssen, 2009), and cultural fields in transition (Dowd, Janssen \& Verboord, 2009). Without Kees, not only would Poetics not be in the position it is in today, it is also fair to say that the field of cultural sociology would have looked different.

Also in his own research he tried to innovate and incorporate the latest developments, bringing together insight and methods from the humanities and social sciences. Kees' research focused on the institutional analysis of the cultural field-the collection of organizations and agents performing particular tasks and pursuing specific interests in the production, distribution, and consumption of symbolic goods. More specifically, this approach asks how organizational forms and practices in the cultural field evolve with the aim to illuminate the dynamics of institutional change in a field-theoretic and institutional logics perspective.

He developed the theoretical foundations of the sociology of book reviewing and cultural coverage in the media that many scholars have benefited from ever since (Van Rees, 1983; 1987). He analyzed literary careers using event history analysis (Van Rees \& Vermunt, 1996). He was one of the first scholars to study cultural omnivores after Richard Peterson, applying the newly developed statistical technique Latent Class Analysis by Jeroen Vermunt (Van Rees, Vermunt \& Verboord, 1999). He collaborated with Koen van Eijck in a series of articles mapping and explaining media use repertoires in the Netherlands since the 1970s (e.g. Van Eijck \& Van Rees, 2000). Together with Gillis Dorleijn, he initiated and codirected a large Dutch research project, funded by the Netherlands Organization for Scientific Research (NWO), involving several PhD students at various universities, which mapped developments in the usage of conceptions of literature in the Dutch literary field in the past two centuries (1994-2003, see Van Rees \& Dorleijn, 2001). Their Dutch language edited volume on the production of literature became a widely used text book at Dutch universities (Dorleijn \& Van Rees, 2006). Kees collaborated with stratification sociologist Harry Ganzeboom and literary scholar Dick Schram to push the research agenda of the multicultural society emerging at Dutch secondary schools, in the NWO funded research project Cultural Canons and Cultural Competences (1997-2003).

In recent years, Kees made another major contribution to the field, by serving as the editor of the 'Culture and the Arts' section of the International Encyclopaedia of the Social and Behavioural Sciences (2nd ed., Elsevier, 2015). He remained active as scholar until the very end; he passed away while reading a book chapter about the cultural impacts of globalization and enjoying a glass of red wine.

Besides all his academic contributions, Kees was also a great mentor and wonderful person. He was one of the friendliest, most generous, and wisest persons that one can meet in the academic field (which, as most of us know, can be a field of struggles, to refer to Bourdieu). He helped young scholars wherever he could, connected people, was always constructive, and showed genuine interest in the persons he met. Because he was such a kind man, it is hard to say goodbye. He will stay forever in our thoughts and hearts.

By Marc Verboord \& Susanne Janssen 


\section{References}

Bourdieu, P. (1983). The field of cultural production, or: The economic world reversed. Poetics, 12(4-5), 311-356.

Bourdieu, P. (1985). The market of symbolic goods. Poetics, 14(1-2), 13-44.

DeNora, T. (1999). Music as a technology of the self. Poetics, 271(1), 31-56.

Dimaggio, P., \& Stenberg, K. (1985). Why do some theatres innovate more than others? An empirical analysis. Poetics, 14(1-2), 107-122.

Dorleijn, G., \& Van Rees, K. (2006). De productie van literatuur. Het Nederlandse literaire veld 1800-2000. Nijmegen: Vantilt.

Van Rees, C. J. (1983). How a literacy work becomes a masterpiece: On the threefold selection practised by literary criticism. Poetics, 12(4-5), 397-417.

Van Rees, C. J. (1987). How reviewers reach consensus on the value of literary works. Poetics, 16(3-4), $275-294$.

Van Rees, K. (1992). Editorial notice. Poetics, 21(1-2) p. ix.

Van Rees, K., \& Vermunt, J. (1996). Event history analysis of authors' reputation: Effects of critics' attention on debutants' careers. Poetics, 23(5), 317-333.

Van Rees, K., Vermunt, J., \& Verboord, M. (1999). Cultural classifications under discussion latent class analysis of highbrow and lowbrow reading. Poetics, 26(5-6), 349-365.

Verdaasdonk, H., \& Van Rees, C. J. (1977). Reading a text vs. analyzing a text. Poetics, 6(1), 55-76.

Van Eijck, K., \& Van Rees, K. (2000). Media orientation and media use. Television viewing behavior of specific reader types from 1975 to 1995. Communication Research, 27, 574-616.

Van Rees, K., \& Dorleijn, G. J. (2001). The eighteenth-century literary field in Western Europe: The interdependence of material and symbolic production and consumption. Poetics, 28(5-6), 331-348.

Lamont, M., Schmalzbauer, J., Waller, M., \& Weber, D. (1996). Cultural and moral boundaries in the United States: Structural position, geographic location, and lifestyle explanations. Poetics, 24(1), 31-56.

Lizardo, O. (2005). Can cultural capital theory be reconsidered in the light of world polity institutionalism? Evidence from Spain. Poetics, 33(2), 81-110.

Mohr, J. W. (1994). Soldiers, mothers, tramps and others: Discourse roles in the 1907 New York City charity directory. Poetics, $22(4), 327-357$.

Peterson, R. A. (1985). Six constraints on the production of literary works. Poetics, 14(1-2), 45-67.

Peterson, R. A. (1992). Understanding audience segmentation: From elite and mass to omnivore and univore. Poetics, 21(4), 243-258.

Marc Verboord*

Dept. of Media and Communication - FHK, Erasmus Universiteit, P.O. Box 1738, 3000 DR, Rotterdam, Netherlands

E-mail address: verboord@eshcc.eur.nl

Susanne Janssen

Erasmus Universiteit, Rotterdam, Netherlands

E-mail address: s.janssen@eshcc.eur.nl

\footnotetext{
* Corresponding author.
} 